\title{
THE QUASI EXPERIMENTAL STUDY OF THE INFLUENCE OF ADVERTISING CREATIVITY AND EXPOSURE INTENSITY TOWARD PURCHASING ACTION WITH AIDA APPROACH
}

\author{
Ramdan Budiawan \\ Faculty of Management and Business \\ Bogor Agricultural University, Bogor, Indonesia \\ E-mail: ramdanb@gmail.com \\ Arif Satria \\ Faculty of Human Ecology \\ Bogor Agricultural University, Bogor, Indonesia \\ E-mail: arifsatria@gmail.com \\ Megawati Simanjuntak \\ Faculty of Human Ecology \\ Bogor Agricultural University, Bogor, Indonesia \\ E-mail: mega.juntakipb@gmail.com \\ Submission: $23 / 08 / 2016$ \\ Revision: 31/08/2016 \\ Accept: 03/10/2016
}

\section{ABSTRACT}

Advertisement is one of marketing communication forms made by companies to reach sales goal of certain product. Advertising creativity is one of important factors that determine the success of television advertisement. Furthermore, the exposure intensity is also a determining factor to make television viewers draw their attentions to television advertisements. In this research, AIDA model is used to measure the viewers' response toward the advertisement. AIDA (Attention, Interest, Desire and Action) model is one of popular response hierarchy models for marketer as guidance to implement the marketing communication activities. This research analyzes the influence of advertising creativity and exposure intensity toward purchasing action as the final stage of consumer in deciding product purchased. The research applied quasi experimental study to 80 respondents as the target market of the advertised product, which is ice cream premix from Haan brand. 
INDEPENDENT JOURNAL OF MANAGEMENT \& PRODUCTION (IJM\&P)

http://www.ijmp.jor.br

v. 8, n. 2, April - June 2017

ISSN: 2236-269X

DOI: 10.14807/ijmp.v8i2.526

The experiment was done in 2 treatments: treatment 1 is one advertising exposure and treatment 2 is three advertising exposures. The Mann Whitney difference test with SPSS program showed no significant differences between one exposure and three exposures. The SEM PLS analysis showed that advertising creativity influenced significantly to attention, interest, desire and action in buying product.

Keywords: Advertising Creativity, Advertising Exposure Intensity, Attention, Interest, Desire, Action

\section{INTRODUCTION}

Consumer need is a very powerful motivation for company to produce product or develop existing product to fulfill what consumers want. The core of business basically starts from the emerging needs of two parties, consumers that need products since they cannot produce, and producers that are able to fulfill the needs of consumers to obtain return for the service. One of the ways to create consumer needs is to provide marketing strategy through advertising concepts.

A creative advertising concept is considered effective to dig the consumer needs for a certain product. TV advertisement still become the mainstay for marketing campaign. It is expected that by using research data, good advertising campaign will be produced. Most advertising costs are expended for top line advertisement, where media plays important roles.

The limited budget Advertisements of several companies could be optimized by formulating effective advertising concepts. An eeffective TV advertisement functioning as marketing communication media is expected to influence the consumer attitude. The consumer attitude is an important factor to consumer decision making (OKTORIYANA; SUMARWAN; HARTOYO, 2014).

Based on AIDA model (STRONG, 1925), an advertising promotion needs sufficient information about behavioral patterns, needs, and market segments. The concept aims to make consumers capable of buying continuously. Any efforts of advertisement with persuasive language attempt to make consumers consume, without considering their social status. AIDA model is one of response hierarchy models that popular for marketing as guidance in implementing the marketing activities.

During the informational message receiving, society or target should pass formulation stages of AIDA concept. First is attention which indicates that the 
INDEPENDENT JOURNAL OF MANAGEMENT \& PRODUCTION (IJM\&P)

http://www.ijmp.jor.br

v. 8, n. 2, April - June 2017

ISSN: 2236-269X

DOI: 10.14807/ijmp.v8i2.526

information or media should be able to attract the target. Second is interest which means that the information or media used relates with how the consumer put interest and further desires. Third, is desire which signifies that the used information or media should be able to drive target's desire to posses or enjoy the product. Last is action which represents the used information or media should have a persuasive power for buyer candidates to do purchasing action as soon as possible (ROFIQ; ARIFIN; WILOPO, 2013).

The goal of the research is to analyze the creativity of TV advertising concept, intensity of advertising exposure and attention, interest, desire, action to buy products. The problems that will be responded in the research are:

1. What are the differences of attention, interest, desire, and action to buy product based on advertising exposure intensity?

2. How much do creativity and intensity of advertising exposure influence attention, interest, desire and action to buy products?

3. What are direct and indirect factors that influence purchasing action?

\section{LITERATUR REVIEW AND FRAMEWORK}

\subsection{Advertising Creativity, Exposure Intensity and AIDA}

Creativity is the capability to present new ideas. Creativity is always used in advertising, because through creativity advertisements will be able to give information, to persuade, to remind, and to improve values of a product. A creative advertisement is able to differentiate itself from the mass usual advertisements, different and unusual advertisements.

An advertisement which is similar with most existing advertisements will be unable to breakthrough the crowd of competitive advertisements and unable to attract the attention of consumers. Although a simple explanation about creativity cannot be found, Jazz musician Charlie Mingus' opinion can give a better explanation about creativity that is "creativity more than make a difference. Everyone can play something strange. The difficulty is to be simple as Bach (classical musician maestro). Creating something simple to be complicated is usual, but making something complicated to be simple is amazing; that is creativity" (LOU CENTIVRE in SHIMP, 2000).

Defining an effective advertisement will be easy if we think that an effective advertisement is an advertisement that is able to reach the expected goals. The 
INDEPENDENT JOURNAL OF MANAGEMENT \& PRODUCTION (IJM\&P)

http://www.ijmp.jor.br

v. 8, n. 2, April - June 2017

ISSN: 2236-269X

DOI: 10.14807/ijmp.v8i2.526

perspective defines the advertising creativity from what outcome obtained (SHIMP, 2000).

An effective advertisement is an advertisement that is created for specific customers, that thinks and understands about the consumer needs. Besides that, an effective advertisement is an advertisement that is able to communicate specific benefits, and to suggest specific actions should be taken by consumers. An effective advertisement understands that people do not buy products but they purchase the benefits of the products. Furthermore, an effective advertisement is an advertisement that get attention and is remembered, and make people do purchasing actions (SCHULTZ; TANNENBAUM in SHIMP, 2000).

A creative advertisement has a role in improving public awareness, but an advertisement cannot be considered successful if it only improves the awareness. An advertisement should create interest and desire that will drive the consumers to buy the advertised products. A creative strategy according to an advertising perspective is a marketing orientation given to creative persons as guidance in making advertisements. For creative persons, a creative strategy is often considered as the interpretation of various information about market product, and the target consumers put into certain position in communication which can be used to formulate advertising goals (KASALI, 1992).

AIDA is the most often used formula to plan a comprehensive advertisement, and implemented at the media selection, advertisement space size, and the position in the publication media. AIDA model (attention, interest, desire, action) is a popular response hierarchy model for marketer as guidance in conducting marketing activities (JEFKINS, 1997).

Several researches explaining the influence of advertising creativity toward buying intention argue that: "attitude toward brands can be improved through effective advertisements in which the creatifity of advertisements and the credibility of endosers are the two influencing factors" (HANDOKO, 2006).

The other research shows that there is a connection and a positive influence between advertising creativity and the needs for uniqueness of consumers' attitude and interest to buy certain products. On the other hand, the research also indicates that no significant influence and relationship between advertisement creativity and needs for recognition of consumers' attitude and interest to buy. So, in relation to the advertisement creativity, it indicates that the factor of need for uniqueness influences 
INDEPENDENT JOURNAL OF MANAGEMENT \& PRODUCTION (IJM\&P)

http://www.ijmp.jor.br

v. 8, n. 2, April - June 2017

ISSN: 2236-269X

DOI: 10.14807/ijmp.v8i2.526

more in attitude and interest to buy compared with the factor of need for cognition (ALAM, 2011).

Research done by Ranjbarian, Shaemi and Jordan (2011) revealed that TV advertisement of electrical conservation was effective. TV advertisements can even get consumers' attention, create interest and desire to act, and finally can change behavior effectively.

The other research related to AIDA carried out by Schaefer, Parker and Haytko (2011) who analyzed about the consumer perception in China and US about CAES (Celebrity Athlete Endorsers) in the relation with AIDA showed that CAES influenced consumers in China and US, Chinese consumers were more affected.

A research done by Fazri (2009) concerning the exposure level of TVC advertisement that was effective in cost to produce attention, interest, desire and action of consumers in Jambi city concluded that to produce consumers' attention and interest for goods, the TVC advertisement is an effective media. Furthermore, the advertisement was needed to be exposed three times.

Sharma (2012) stated that there should be creativity element in advertising. The creativity was to create something new, unique, and interesting for consumers. Even the advertisement itself was a creative process. The creativity made the advertisement become popular to the consumers so that they wanted to buy certain products.

Mercanti (2008) stated that an advertisement was considered as creative by consumers if it included three dimensions: novelty, complexity, and aesthetic. Novelty signified the unexpected second stimulus association and relevance with the advertisement. Complexity was related to meaningful advertisements. Aesthetic indicated a special design for creative advertisements.

Modig and Rosengren (2004) stated that creativity in advertisement provided product quality signals. A creative advertisement might become one of potential strategies for retailers to decrease consumer price sensitivity.

Bellman et al. (2010) believing in two notions about minimum effective frequency of ordinary TV advertisement or minimalist stated that the minimum frequency is one, while the repetitions stated that the minimum frequency should be higher. The general rules used by repetitions indicated that there were three sufficient exposures. In early 1970s, Krugman stated that the fist exposure triggerred 
the cognitive curiosity, second exposure produced evaluation and third exposure produced action.

Makienko (2011) stated that there were two opinions about the optimal amount of exposures to maximize consumer responses to advertisement related to its role in market. The first opinion stated that advertisement was a persuasive and communicative tool that was able to convince the consumers to buy the advertised products after one exposure. While other opinion stated that advertisement had insignificant influence and was saved as memory and due to that fact, it should be repeated to create several effects to consumers. This opinion suggested that advertiser should focus on the frequency.

Bach and Lund (2007) stated that the goal of marketing communication was to create consumer responses, in which an individual would pass through a series of response levels that was seen as a hierarchy effect. The widely used method is AIDA (attention, interest, desire, action). Through the model, we could assume that individuals would be interested in the products before allocate their attentions.

Sadeh et al. (2013) stated that the messages revealed through media to communicate with consumers should follow AIDA model framework, that is attracting receiver attention, encouraging their desire and finally directing to their action. Different media causes different reaction depending on their unique effects on the receivers.

\subsection{Research Framework}

The researcher want to know how far the influence of advertising creativity toward attention, interest, desire and action to buy product, then it is made model or conceptual framework that support the research hypothesis. The independent variable in the research was advertising creativity and the dependent variables were attention, interest, desire and action to buy product. Model or conceptual framework in the research can be seen in figure 1. 


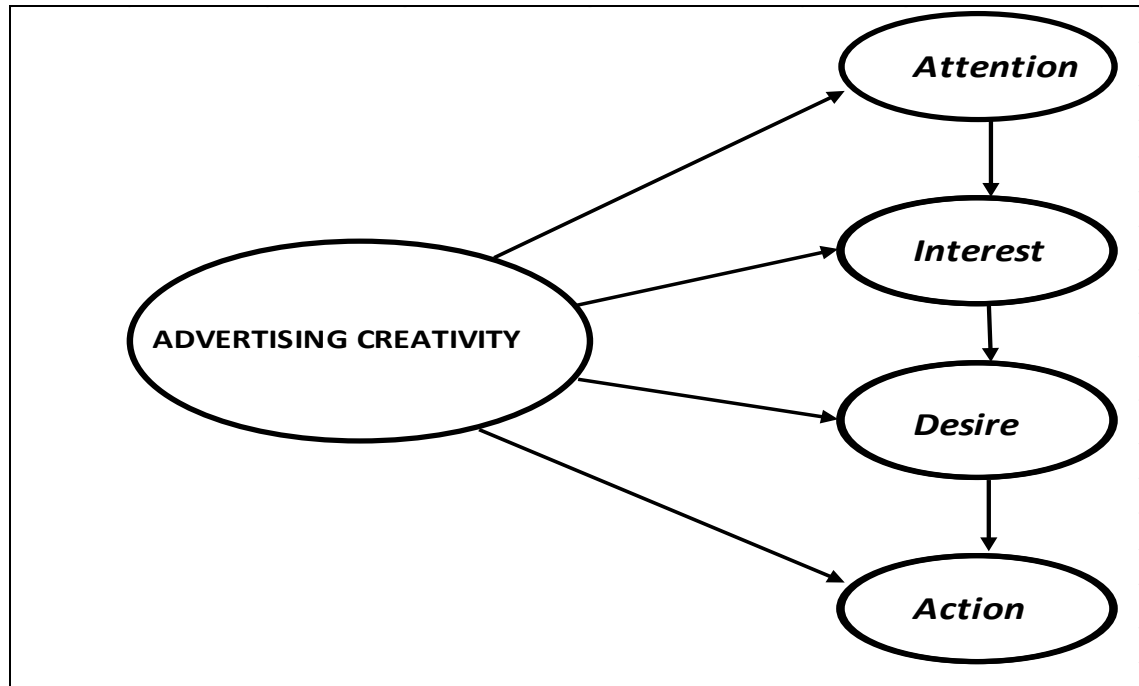

Figure 1: Research framework

\section{RESEARCH METHOD}

The research is about the influence of advertising creativity and exposure intensity on purchasing action using AIDA approach carried out by quasi experimental method in several mother communities that comply with the target market of ice cream premix produced by Haan brand in Bogor and Bandung area. The research and experiment were done during February and March of 2016.

The model used in the research was a predictive relationship model and to analyze the proposed research hypothesis, PLS-SEM or partial least square path modeling was applied. The second method used to analyze the differences of two treatments applied in the research experiment was a SPSS program. In the quasi experiment, the data was collected by giving questionnaires to the research subjects in three experiments. There were 80 collected questionnaires used and processed as the research data.

The dependent variable of this research was the decision of purchasing action. The independent variables were influence, advertising creativity and exposure intensity.Then there were variables that serve as independent and dependent variables. They were attention, interest, and desire. As part of the advertising creativity, there were 3 dimensions measured in this research, namely: advertising themes, advertising jingles and advertising slogans. The SEM model of the research can be seen in figure 2 . 


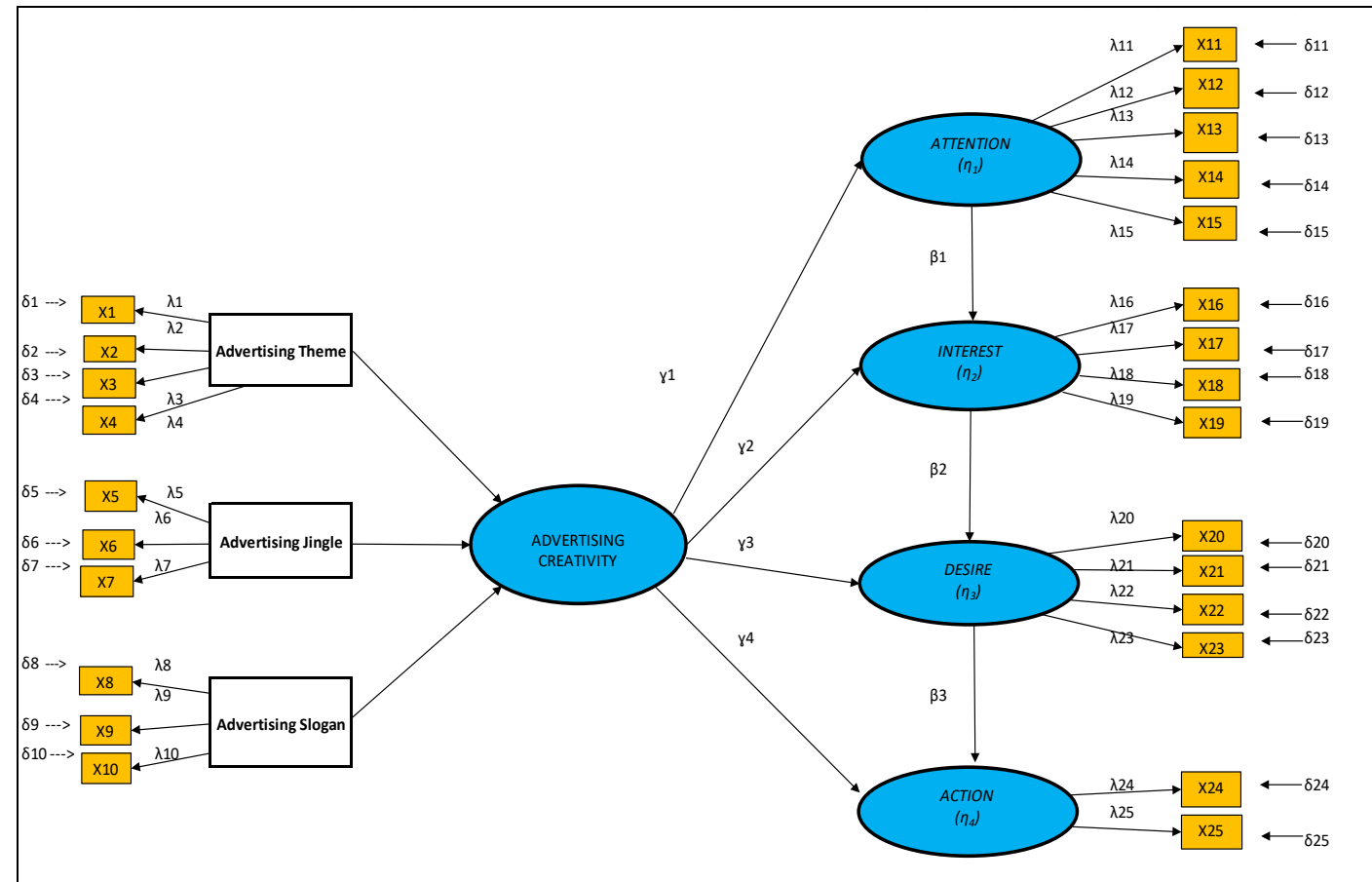

Figure 2: SEM PLS Model of Research

\section{RESULTS AND DISCUSSION}

\subsection{Descriptive analysis of research variables}

The research instruments include various questions made for 25 indicators that consist of 10 questions of advertising creativity, 4 indicators representing advertising theme, 3 indicators signifying advertising jingle, and 3 indicators representing advertising slogan. The other 5 indicators are from attention variable, 4 indicators are from interest variable, 4 indicators are from desire variable and 2 indicators are from action variable. The results can be seen from the replies of the research subjects given in table 1 below.

The advertising theme as a part of the parameters in creativity work served as independent variable in this reaseach. From experiments conducted using 1 exposure treatement or 3 exposures treatment, indicators that have the highest score is the indicator of advertisement as reminder of the product advantage and the lowest one is the indicator of advertisement which is being different from other advertisements. The result has concluded that TV viewers mostly give their attention to the product advantage aired in the advertisement. Only few spectators consider that the advertisement should be different from other advertisements. 
DOI: 10.14807/ijmp.v8i2.526

Table 1: Average score of dimension indicators and research variables

\begin{tabular}{|c|c|c|c|c|}
\hline \multirow[b]{2}{*}{ Variable } & \multirow[b]{2}{*}{ Dimension } & \multirow[b]{2}{*}{ Indicator } & \multicolumn{2}{|c|}{ Mean } \\
\hline & & & Once & $\begin{array}{l}\text { Three } \\
\text { Times }\end{array}$ \\
\hline \multirow{3}{*}{$\begin{array}{l}\text { Advertising } \\
\text { Creativity }\end{array}$} & $\begin{array}{c}\text { Advertising } \\
\text { Theme }\end{array}$ & $\begin{array}{l}\text { Stimulus (interesting) } \\
\text { Remind the value of product } \\
\text { Different with other advertising } \\
\text { Endorser as the attractor }\end{array}$ & $\begin{array}{l}3.41 \\
3.89 \\
3.02 \\
3.41\end{array}$ & $\begin{array}{l}3.67 \\
4.10 \\
3.33 \\
3.74\end{array}$ \\
\hline & $\begin{array}{c}\text { Advertising } \\
\text { Jingle }\end{array}$ & $\begin{array}{l}\text { Make the brand easy to remember } \\
\text { Communicate information about product } \\
\text { Fun and interesting }\end{array}$ & $\begin{array}{l}3.56 \\
3.7 \\
3.34\end{array}$ & $\begin{array}{l}3.77 \\
3.87 \\
3.90\end{array}$ \\
\hline & $\begin{array}{c}\text { Advertising } \\
\text { Slogan }\end{array}$ & $\begin{array}{l}\text { The sentence is interesting for spectators } \\
\text { The sentence is easy to remember } \\
\text { Influence consumers to use product }\end{array}$ & $\begin{array}{l}3.49 \\
3.61 \\
3.68\end{array}$ & $\begin{array}{l}3.79 \\
3.74 \\
3.95\end{array}$ \\
\hline \multicolumn{2}{|c|}{ Attention } & $\begin{array}{l}\text { Interesting because of the practical product } \\
\text { Interesting because of the product benefit for family } \\
\text { Interesting because the product is liked by children } \\
\text { Interesting because the brand is easy to remember } \\
\text { Interesting because of superior product could be } 2 \text { in } 1\end{array}$ & $\begin{array}{l}4.24 \\
4.1 \\
4.1 \\
4.0 \\
4.0\end{array}$ & $\begin{array}{l}4.28 \\
4.26 \\
4.31 \\
4.05 \\
4.33\end{array}$ \\
\hline \multicolumn{2}{|c|}{ Interest } & $\begin{array}{l}\text { Generate interest because the product is liked by children } \\
\text { Generate interest because become a new idea in ice cream presentation } \\
\text { Generate interest because easy in production } \\
\text { Generate interest because it is economic }\end{array}$ & $\begin{array}{l}3.98 \\
3.90 \\
4.30 \\
4.17\end{array}$ & $\begin{array}{l}4.08 \\
3.97 \\
4.15 \\
4.08\end{array}$ \\
\hline \multicolumn{2}{|c|}{ Desire } & $\begin{array}{l}\text { Generate desire to try because the product is liked by children } \\
\text { Generate desire to try because the product is suitable with the need } \\
\text { Generate desire to try because can make in home } \\
\text { Generate desire to try because the product is economic }\end{array}$ & $\begin{array}{l}4.00 \\
3.83 \\
4.19 \\
3.83\end{array}$ & $\begin{array}{l}4.05 \\
3.8 \\
3.95 \\
4.05\end{array}$ \\
\hline \multicolumn{2}{|c|}{ Action } & $\begin{array}{l}\text { Statement will buy product } \\
\text { Statement will recommend the product to others }\end{array}$ & $\begin{array}{l}3.69 \\
3.71\end{array}$ & $\begin{array}{l}3.79 \\
3.77\end{array}$ \\
\hline
\end{tabular}

Dimension in the advertising creativity variable which is the advertising jingle in this research are measured by 3 indicators: to make the brand easy to remember, to communicate the information of the products, to perceive producsts as interesting and joyful. From the three indicators, at treatment of 1 exposure, the highest score was on communicating product information indicaor. While at treatment of 3 exposures, the highest score was on perceiving fun and interesting object indicator.

The third dimension in measuring the advertising creativity was advertisement slogan that was measured by 3 indicators, interesting sentences that can steal viewers' attention, easy-to-remember sentences and influential ability to make consumer use the product. From both treatment, either the experiment using1 
exposure or the esperiment using 3 exposures, the highest indicator was influential ability to make consumers use the product.

At Attention variable which was the first response of the research subject on advertising creativity, the highest score of treatment using1 exposure was the practical product advantage indicator, while for treatment using 3 exposures the highest score was the 2 in 1 product advantage indicator. From the results, it can be seen that the practicability product advantage and 2 in 1 product advantage were the the two factors that attract the viewers the most.

Other variable which was the response parameter of consumers on advertising creativity was interest variable or variable of consumer interest generating. From the experiment of treatment using either 1 or 3 exposures, the highest indicator was generating interest because easily produced. It showed that the advertisement was successful in delivering messages to consumers. The ice cream is easy to make.

For action variable, the highest indicator of the treatment using 1 exposure was the statement that expressed the willingness to recommend the products to other people and for the treatment using 3 exposures, the highest score was on the statement of willingness to buy the advertised products.

\subsection{Evaluation of Fit Model}

\subsubsection{Assess the outer model or measurement model}

There are three principles of data analysis using SmartPLS to assess the outer model, namely: convergent validity, discriminant validity and composite reliability.

\section{1) Convergent Validity}

Convergent validity of the measuring model with reflexive indicator was assessed based on the correlations between item score or component score which estimated by PLS software. The individual reflexive size was considered high if it correlates more than 0.70 with the measured variable. But according to Chin (1998) in Ghozali (2008) for initial stage research the value measurement scale of loading factor of 0.5 to 0.6 was considered as sufficient. this research applied loading factor of 0.5 . 
The processing results by using SmartPLS at 1 exposure treatment, the outer model value or correlations between variable with other variable shows that almost all indicators have loading factor value more than 0.50 except JI5 of 0.495 . So, the indicator was removed. Model figure of SEM PLS after one insignificant indicator was removed given in figure 3 .

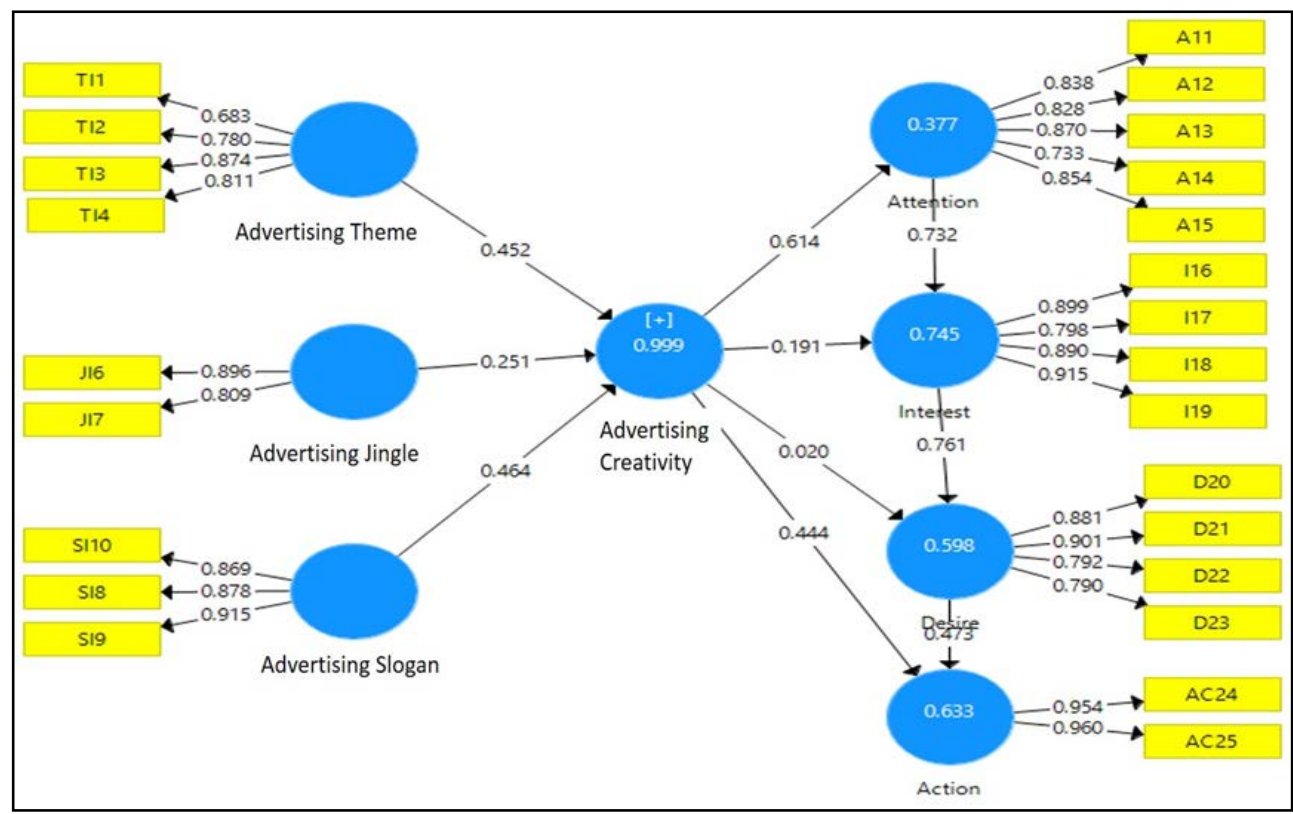

Figure 3: SEM PLS Model of 1 exposure treatment after elimination

At the dimension of advertising theme, the most significant influence was T13 indicator, which made the advertisement difference from other advertisements. At the dimension of advertisement jingle, the most significant was $\mathrm{J} 16$ indicator that was the ability to communicate product information. For the advertising slogan, the significant one is S19 indicator that was easy-to-remember sentences.

For attention, A13 was a significant variabel which indicated that product was interesting because children like it. The most significant indicator at the interest variable was I19, product generates interest because it was economical. For desire, , D21 was the most significant variable which indicated that the desire to try would be generated because the product was suitable for the needs. For action, which was the indication of consumer purchasing decision, the most significant variabel was the willingness to recommend the product to other people. it showed the subject strong desire toward the product.

For treatment of 3 exposure, the all loading factor value more than 0.5 as given in figure 3. The outer model value or correlation among variable has fulfilled convergent validity because all indicators have loading factor value more than 0.50 . 
INDEPENDENT JOURNAL OF MANAGEMENT \& PRODUCTION (IJM\&P)

http://www.ijmp.jor.br

v. 8 , n. 2, April - June 2017

ISSN: 2236-269X

DOI: 10.14807/ijmp.v8i2.526

The strongest indicator was perceived as interesting and fun object. The strongest indicator at the advertising slogan dimension is easy-to-remember sentences. The processing by using SmartPLS produced model as given in figure 4 .

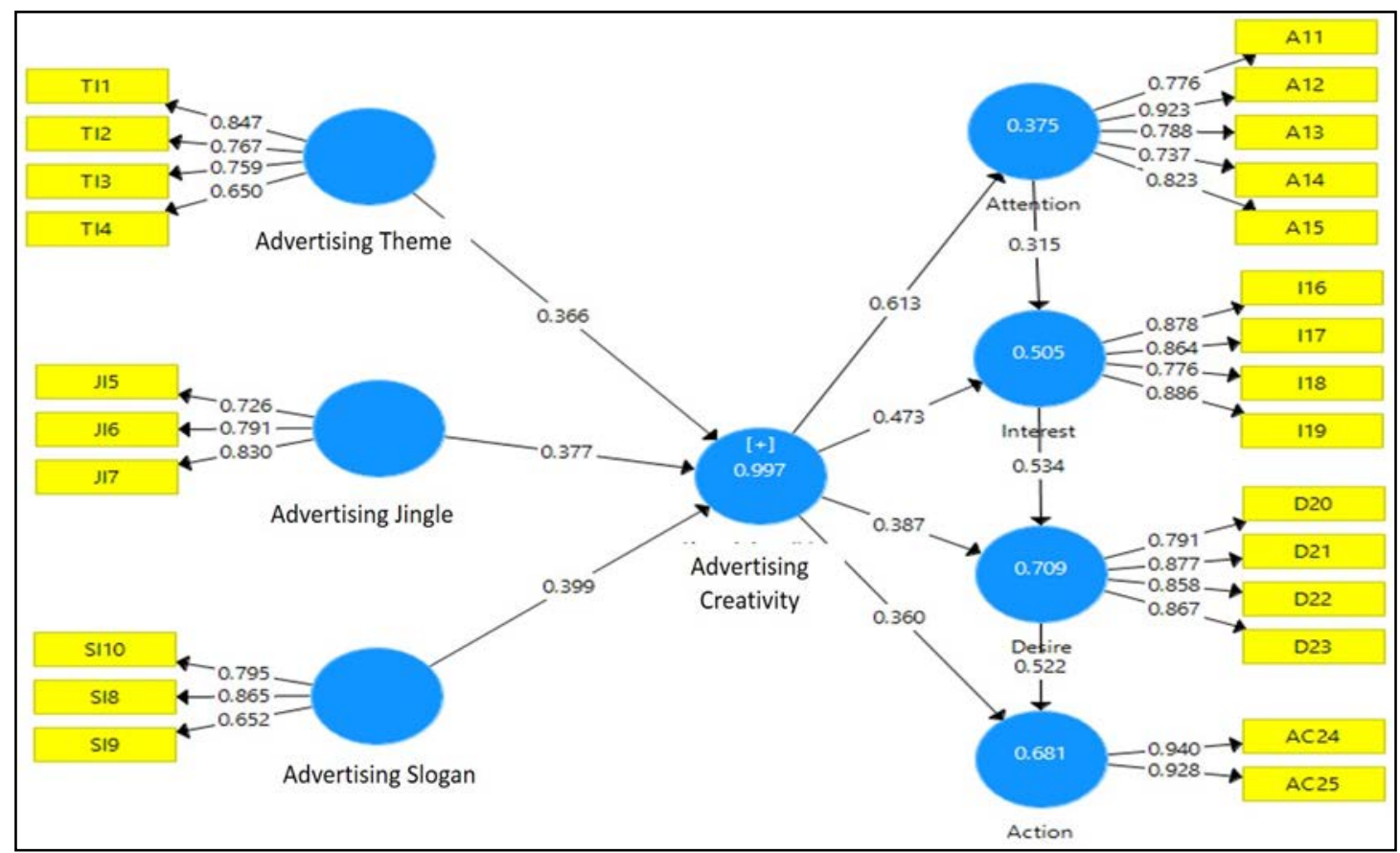

Figure 4: SEM PLS model of 3 exposures

At other variable, that was attention variable, the strongest indicator was interesting because it was a family product. At the interest variable the strongest indicator was interest generating due to economical aspect, while for desire variable, the strongest indicator was interest generating due to the need suitability. The consumer statement toward buying intention indicator scored more than 0.9 each. It showed that the consumer desire to buy the product was strong.

2) Discriminant Validity

Discriminant validity was an indicator measurement with the latent variable. The discriminant validity measurement was done by looking at the AVE root square for each variable. If the AVE root square value for each variable $>0.5$, then it could be concluded the construct has good a discriminant validity. The discriminant validity test in the research produced AVE root square value $>0.5$ for all variables and dimensions.

\section{3) Composite Validity}

Validity and reliability criteria could also be seen from the reliability value of variable and average variance extracted (AVE) of each variable. A variable could be perceived as high reliability if the composite reliability value was above 0.70 and 
AVE was above 0.50 . The test results for the research informed that all variables fulfilled the composite reliability because the value was above 0.7 , as the recommended value.

Based on the entire evaluation results concerning convergent validity, discriminant validity, composite reliability that has been explained above, it could be concluded that the indicators as the latent measurement variables were valid and reliable measure.

\subsubsection{Inner Model}

Inner model or structural model test was carried out to know the relationship among variables, which are the significance value and $\mathrm{R}$ square of the research model. The structural model was evaluated by using R-square for dependent variable of t-test and significance of structural path parameter coefficient. Figure 4 showed the estimation results of R-square by using SmartPLS program.

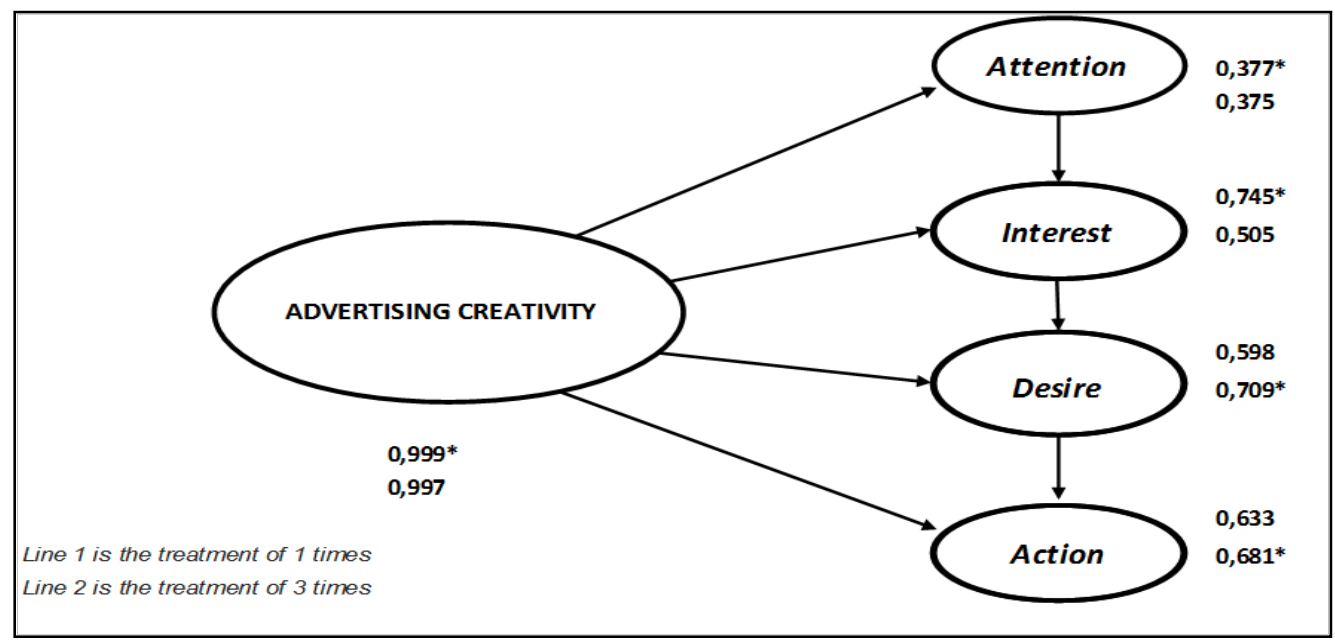

Figure 5: R-square value

From figure 4 , for treatment of 1 exposure, R-square value of attention construct was 0.377 that means 37.7 percent of advertising creativity variance could be explained by attention variable while the remaining was explained by other variables. The interest variable had R-square of 0.745 that means 74.5 percent of variant creativity of advertisement and attention could be explained by interest variable, while the remaining was explained by other variables. If the value of $R$ square was high, the ability of the independent variable to explain the dependent variable was also high, so that the structural equation was better. The desire variable had R-square of 0.598 that meant 59.8 percent of variant of the advertising creativity and interest could be explained by desire variable, while the remaining was 
explained by other variables. Action variable had R-square of 0.633 that meant 63.3 percent of advertising creativity variable and desire could be explained by action variable while the remaining was explained by other variables.

For the R-square of 3 exposures treatment, attention construct had R-square of 0.375 that meant 37.5 percent of advertising creativity variable could be explained by attention variable while the remaining was explained by other variables. Interest variable had R-square of 0.505 that meant 50.5 percent of advertising creativity variable and attention could be explained by interest variable and the remaining was explained by other variables. Desire variable had R-square value of 0.709 that meant 70.9 percent of desire variable could explain the advertising creativity variable and interest variable while the remaining was explained by other variables. Action variable had R-square of 0.681 that meant 68.1 percent of advertising creativity variable and desire variable could be explained by action variable and the remaining was explained by other variables.

\subsection{Hyporesearch testing}

For hyporesearch testing $1(\mathrm{H} 1)$, measuring the differences between 2 treatments using 1 exposure and 3 exposures, Mann Whitney $U$ test with SPSS program was carried out. The data analysis using Mann Whitney $U$ test obtained the results as given in table 2 .

Table 2. Difference test of Independent T-test

\begin{tabular}{|c|c|c|c|c|c|c|c|c|c|}
\hline \multirow{2}{*}{$\begin{array}{l}\text { Variable/ } \\
\text { dimension }\end{array}$} & \multicolumn{4}{|c|}{ Treatment of 1 exposure } & \multicolumn{4}{|c|}{ Treatment of 3 exposures } & \multirow{2}{*}{$\begin{array}{c}\text { Difference } \\
\text { test } \\
\text { between } \\
\text { treatment }\end{array}$} \\
\hline & Average & SD & Minimum & Maximum & Average & $\mathrm{SD}$ & Minimum & Maximum & \\
\hline $\begin{array}{l}\text { Advertising } \\
\text { creativity }\end{array}$ & 62.87 & 13.60 & 22.50 & 100.00 & 69.68 & 11.54 & 45.00 & 90.00 & 0.018 \\
\hline $\begin{array}{l}\text { Advertising } \\
\text { theme }\end{array}$ & 60.82 & 16.12 & 25.00 & 100.00 & 67.79 & 14.59 & 37.50 & 93.75 & 0.046 \\
\hline $\begin{array}{l}\text { Advertising } \\
\text { jingle }\end{array}$ & 63.62 & 15.11 & 33.33 & 100.00 & 71.15 & 13.22 & 33.33 & 100.00 & 0.020 \\
\hline $\begin{array}{l}\text { Advertising } \\
\text { slogan }\end{array}$ & 64.84 & 18.21 & 0.00 & 100.00 & 70.73 & 12.07 & 50.00 & 100.00 & 0.094 \\
\hline Attention & 78.29 & 13.68 & 45.00 & 100.00 & 81.15 & 12.90 & 50.00 & 100.00 & 0.339 \\
\hline Interest & 76.52 & 16.22 & 25.00 & 100.00 & 76.76 & 16.53 & 37.50 & 100.00 & 0.948 \\
\hline Desire & 73.78 & 15.20 & 31.25 & 100.00 & 74.52 & 17.35 & 25.00 & 100.00 & 0.840 \\
\hline Action & 66.77 & 16.91 & 25.00 & 100.00 & 69.55 & 15.91 & 37.50 & 100.00 & 0.451 \\
\hline
\end{tabular}


INDEPENDENT JOURNAL OF MANAGEMENT \& PRODUCTION (IJM\&P)

http://www.ijmp.jor.br

v. 8, n. 2, April - June 2017

ISSN: 2236-269X

DOI: 10.14807/ijmp.v8i2.526

From table 2 above, it could be seen that the results of difference tests for variable with $p$ value $>0.05$ were at the dimension of advertising slogan, attention variable, interest variable, desire variable and action variable. For advertising creativity, advertising theme, advertising jingle the $p$ value was $<0.05$. It showed that the research subject that obtained 3 exposures had more influence at advertising theme and jingle. The average showed that all values at 3 exposures were higher than 1 exposure. This meant that all variables concerning advertising creativity, attention, interest, desire, action to buy product were all better at 3 exposures although in the t-test they showed no significant differences.

In the second hyporesearch test $(\mathrm{H} 2)$, it showed that creativity and intensity of advertising exposure influenced directly and significantly toward attention, interest, desire, and action to buy product. And in the third hyporesearch (H3) using Smart PLS, it was revealed that creativity and advertising exposure intensity influenced indirectly and significantly toward attention, interest, desire, and action to buy product. From the data processing using SmartPLS the results were obtained as given in figure 6 .

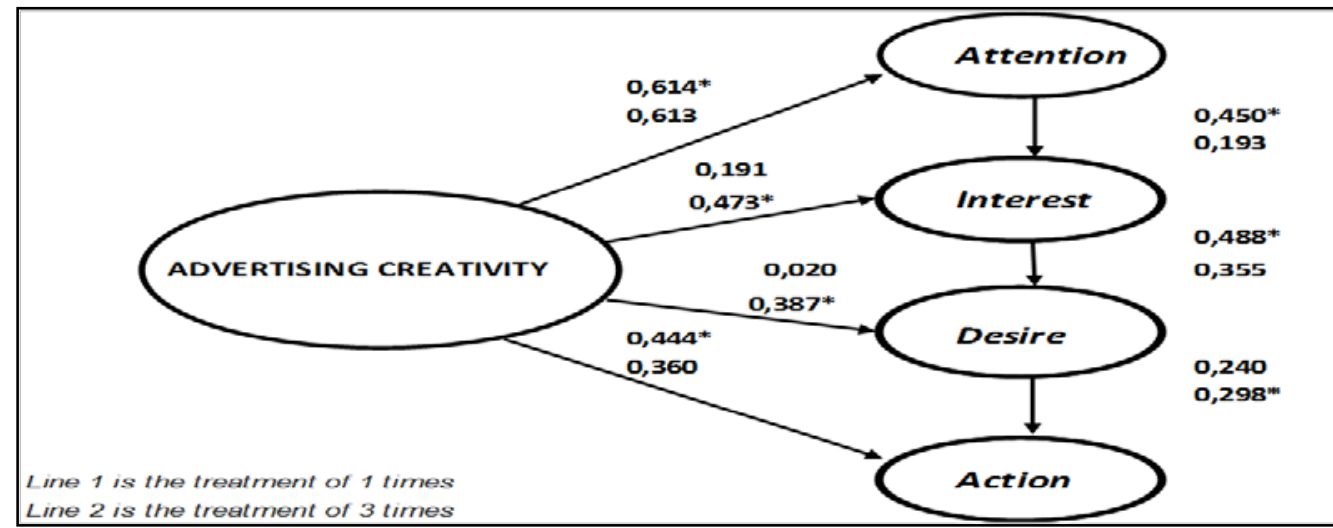

Figure 6: SEM PLS model of the advertising creativity influence toward AIDA

The result analysis of SmartPLS program showed that the creativity influenced positively and significantly upon attention, interest, desire, and action to buy product at the treatment using 3 exposures. At the treatment using1 exposure the creativity did not influence interest and desire directly. It showed that the research subjects who watch the ice cream of Haan brand only once did not generate interest and desire to the product.

In SEM PLS model testing, indirect influence of advertising creativity is applied to interest, desire and action variables, and direct influence was applied only to attention. The result analysis of SmartPLS using 1 exposure showed that 
advertising creativity influenced indirectly and significantly upon interest, desire, and action. While at 3 exposures, indirect influence of the creativity only showed significance at the desire and action variables.

\section{CONCLUSIONS AND SUGGESTIONS}

Based on the results then it can be concluded that no significant differences at the treatment to the subjects in the form of exposure intensity of once or 3 times. It showed that the result of giving 1 exposure was almost similar with 3 times exposures. So, the management while doing marketing strategy by using advertisement on television, should increase numbers of television programs to air with low intensity to reach more viewers rather than airing it on few television programs with high intensity. It was useful for limited budget company.

Advertising creativity influenced directly and significantly upon attention, interest, desire and action to buy product. Advertising creativity influenced indirectly and significantly upon interest, desire, and action to buy product. It showed that ice cream of Haan brand as object in the research was appropriate to be aired in television as marketing communication strategy to increase the attention, interest, desire and action to buy.

For the research it is suggested that the advertising measurement method applied in this research can be used to test the next advertising concept that is going to be aired or carried out as marketing communication strategy. However it is better to create animation similar to the real advertising concept before the real one produced. This will cut down any additional costs of production when there is any correction toward the concept as the result of measurement.

\section{REFERENCES}

ALAM, F. (2011) Pengaruh Kreativitas Iklan, Need For Uniqueness \& Need For Recognition Terhadap Sikap dan Minat Membeli Konsumen. Research (Master of Management). Semarang, Indonesia. University of Diponegoro.

BACH, M.; LUND, A. (2007) Low attention advertising processing in B2B markets. . Journal of Business \& Industrial Marketing, v. 22, n. 5, p. 342-348

BELLMAN, S.; SCHWEDA, A.; VARAN, D. (2010) Minimum effective frequency for interactive television ads. Journal of Direct, Data and Digital Marketing Practice, V. 11, n. 4, p. 281-301.

FAZRI, A. (2009) Measure the effective TVC Exposure to Generate Impact of Attention, Interest, Desire and Action at Consumer of Jambi City. Modern Marketing Management Journal, v. 1, n. 1, p. 25-26. 
GHOZALI, I. (2008) Structural Equation Modeling: Metode Alternatif Dengan Partial Least Square. Semarang, Indonesia : Badan Penerbit Universitas Diponegoro.

HANDOKO, R. S. (2006) Analisis Pengaruh Kredibilitas Endorser dan Kreatifitas Iklan Terhadap Efektivitas Iklan Yang Mempengaruhi Sikap Terhadap Merk (Studi Kasus Iklan Televisi Pada Konsumen Sepeda Motor Honda di Kota Semarang). Research (Master of Management). Semarang, Indonesia. University of Diponegoro.

JEFKINS, F. (1997) Periklanan edisi ketiga. Jakarta, Indonesia : Penerbit Erlangga KASALI, R. (1992) Manajemen Periklanan Konsep dan aplikasinya di Indonesia. Jakarta, Indonesia : Pustaka Utama Grafitti.

MODIG, E.; ROSENGREN, S. (2014) Can advertising creativity affect product perceptions and retailer evaluations?. Journal of Product \& Brand Management, v. 23 , n. 6 , p. 452-461.

MAKIENKO, I. (2011) Effective frequency estimates in local media planning practice. Journal of Targeting, Measurement and Analysis for Marketing, v. 20, n. 1, p. 57-65.

MERCANTI (2008) Consumers' perception of the creativity of advertisements: development of a valid measurement scale. Recherche et Applications en Marketing, v. 23, n. 4, p. 97-99

OKTORIYANA, A.; SUMARWAN; HARTOYO (2014) Perumusan Strategi Pemasaran Fry Counter dengan Pendekatan Model AIDA. Jurnal IImu Keluarga dan Konsumen., v. 7, n. 2, p. 103-112.

RANJBARIAN, B.; SHAEMI, A.; JOLODAR, S. (2011) Assessing the Effectiveness of Electric Conservation Advertisements in Isfahan Channel Television.

International Business Research v. 4, n. 3, p. 194-199

ROFIQ, A.; ARIFIN, Z.; WILOPO (2013) Pengaruh Penerapan AIDA (Attention, Interest, Desire, Action) Terhadap Keputusan Pembelian (Survey Pada Pembeli Kartu Perdana IM3 di Lingkungan Mahasiswa Fakultas IImu Administrasi Universitas Brawijaya Angkatan 2012). Jurnal Administrasi Bisnis, v. 3, n. 1, p. 16-23.

SADEH, D.; NOORAIE, M.; HAJIKARIMI, B. (2013) Billboard advertising optimization by using imperialist competitive algorithm (Case study: Tehran city). African Journal of Business Management, v. 7, n. 36, p. 3706-3713

SCHAEFER, A.; PARKER, S.; HAYTKO, D. (2011) Chinese and U.S. consumers' perceptions of the effectiveness of celebrity athlete endorsers. Journal of Management and Marketing Research.

SHARMA, P. (2012) Advertising Effectiveness: "Understanding the Value of Creativity in Advertising", a Review Study in India. Online Journal of Communication and Media Technologies v. 2, p 2-5

SHIMP, T. A. (2000) Advertising, Promotion, and Other Supplemental Aspects of Integrated Marketing Communications,(5th ed). Hinsdale (US): Dryden Press STRONG, E. (1925) The Psychology of Selling and Advertising, McGraw-Hill, New York 